Jakub Pokoj

Jagiellonian University

ORCID: 0000-0001-7266-5552

\title{
BETWEEN LAW IN THE BOOKS AND LAW IN ACTION: COUNTERACTING SPECULATION AND USURY IN POLAND (1918-1920)
}

\section{INTRODUCTION}

The main aim of this paper is to analyse the phenomena of speculation and usury in the first years after the rebirth of Poland (1918-1920)1. The reborn Polish state inherited a large variety of legal systems which made up a mosaic of regulations. However, from the very beginning of the regained independence, it was a foregone conclusion that it would not be possible to enforce a legal system of one of the occupational powers all over the territory of the Republic or to revive the legal system from before the Partitions. Thus, the only acceptable solution was to sustain the law already in force in particular parts of Poland, despite the fact that such a condition could become a significant obstacle in the process of unification of the state ${ }^{2}$. In order to depict the discrepancies in the Polish legal system, it is enough to mention that at the threshold of independence, the Polish territory consisted of parts where law in force was of different provenance: Austrian, French, German, Hungarian or Russian ${ }^{3}$. This state of uncertainty and disorder forced the Polish elites, firstly, to make efforts in order to uniform the legal system, and

${ }^{1}$ History of Poland in the $20^{\text {th }}$ century is a well examined subject of study in the Englishlanguage literature. The following publications shall be mentioned: N. Davies, God's Playground, Vol. 2, 1795 to the present, Oxford 2005; P.D. Stachura, Poland in the Twentieth Century, London 1999; P.D. Stachura, Poland 1918-1945, London, New York 2004; The History of Poland since 1863, R.F. Leslie (ed.), Cambridge 1980.

${ }^{2}$ S. Płaza, Historia prawa $w$ Polsce na tle porównawczym, Vol. 3, Okres międzywojenny, Kraków 2001, p. 35.

${ }^{3}$ J. Bardach, B. Leśnodorski, M. Pietrzak, Historia ustroju i prawa polskiego, Warszawa 2005, p. 552. 
secondly, to prepare Polish national codifications in various branches of law ${ }^{4}$. Therefore, as soon as in the first half of 1919, the Codification Commission was established ${ }^{5}$.

The Great War, which lasted for more than 4 years, led to permanent shortages of numerous goods. Furthermore, as large parts of the reborn Polish state had been the war zone for some time, the disadvantageous supply conditions were even worse due to the losses resulted directly from the military actions, contributions, requisitions, and plunders. Therefore, the reborn Polish state from the very beginning of its existence had to cope with numerous economic difficulties whose common denominator was scarcity of commodities ${ }^{6}$. Poland was also struggling against some other economic obstacles defined as "structural" 7 Many years of neglecting investments and treating the Polish territories as peripheries of the occupational powers, as well as separating particular parts of Poland from each other by borders abolished just a moment before, posed a serious threat to the Polish economy in a long term. In a shorter period, however, termination of previous trade routes and contacts with business partners from Austria, Germany and Russia, disturbed the production and made it collapse. Moreover, 123 years of occupation was a source of mutual mistrust between the Poles brought up in different states ${ }^{8}$. In addition, from the very beginning of its existence, the Second Polish Republic was involved in military conflicts with most of the neighbouring countries, and thus the state's budget was overwhelmed with military expenses? This set of unfavourable economic circumstances enabled speculation and usury to become widespread across the country.

The general deficiencies of the legal system of the reborn Polish state were also related to the regulations in the field of counteracting speculation and usury. Depending on the part of Poland there could be at least three different regulations in the field of counteracting speculation and usury. The situation was clear in the lands previously annexed by Austria and Germany. In the formerly Austrian lands the imperial Decree on supplying population with usable commodities had been issued on 28 March 1917 and was still binding ${ }^{10}$, whereas in those parts of Poland

${ }^{4}$ S. Grodziski, Komisja Kodyfikacyjna Rzeczypospolitej Polskiej, "Czasopismo PrawnoHistoryczne" 1981, Vol. 33, issue 1, p. 47.

${ }^{5}$ Journal of Laws 1919, issue 44, position 315.

${ }^{6}$ Cf. R. Jastrzębski, Opinia w sprawie możliwości dochodzenia przez Polskę od Niemiec odszkodowania za szkody spowodowane przez druga wojnę światowa w zwiąku z umowami międzynarodowymi, „Przegląd Sejmowy” 2017, Vol. 143, issue 6, p. 210-215.

${ }^{7}$ Cz. Brzoza, A.L. Sowa, Historia Polski 1918-1945, Kraków 2006, p. 170.

${ }^{8}$ W. Pobóg-Malinowski, Najnowsza historia polityczna Polski, Vol. 2, 1919-1939, London 1956, p. 5.

${ }^{9}$ Z. Landau, J. Tomaszewski, Gospodarka Drugiej Rzeczypospolitej, „Dzieje Narodu i Państwa Polskiego" Vol. 63, Warszawa 1991, p. 9

${ }^{10}$ Reichs-Gesetz-Blatt für das Kaiserthum Österreich 1917, No. 131. 
which had belonged to the German Empire the Decree against price increase from 8 May 1918 was in force ${ }^{11}$. Simultaneously, in the Congress Kingdom and in the Eastern Lands, which had previously belonged to Russia, the situation was ambiguous, as there was no single act of legislature which could determine the counteraction against speculation and usury. However, there was a complex of orders and instructions given by the occupational, military and civilian authorities $^{12}$. This state of uncertainty intensified the necessity for adopting a complex of regulations aimed to mitigate the consequences of shortages of numerous commodities caused by the war, including scarcity of first necessity goods. While in the formerly Austrian and German parts of Poland the previously introduced regulations were in force, particularly urgent was the need to adopt new regulations in these parts of Poland which had belonged to Russia.

\section{TERMINOLOGICAL REMARKS}

To introduce the issues of usury and speculation at the threshold of Polish independence after World War I, it is inevitable to at least briefly depict the speculation, usury, and the phenomenon which was constituted under special circumstances by this two - war usury. This part of the paper is designed to prepare a conceptual framework and especially to state some key terminological remarks. As the definitions of speculation and usury have been changing throughout ${ }^{13}$ centuries until nowadays, the commonplace meaning of both these terms is far from the meaning given to them by the interwar legal scholars.

Speculation as an economic phenomenon is especially dangerous for the young economies, deprived of solid foundations. As it was mentioned before, Poland was struggling with this kind of socio-economic situation after the end of the World War I and during the first years of the revived Poland. Therefore, speculation was widespread across the country, especially in those parts which were susceptible to any disturbances due to war losses. However, initially speculation was not perceived as an extraordinary situation and its main outcome high prices - were considered as an independent result of the supply shortages caused by war ${ }^{14}$. Therefore, the foundations for the legal definition of speculation

${ }^{11}$ Reichsgesetzblatt 1918, No. 395.

${ }^{12}$ D. Fajgenberg, Lichwa. Rozprawa doktorska przyjęta przez Radę Wydziatu Prawa Uniwersytetu Warszawskiego, Warszawa 1932, p. 93.

${ }^{13}$ Cf. D. Fajgenberg, Lichwa ..., pp. 16-42.

${ }^{14} \mathrm{~J}$. Reinhold, Ustawa o zwalczaniu lichwy wojennej wraz z odnośnemi rozporządzeniami Ministra Aprowizacji, Warszawa, Kraków 1921, p. 5. 
were strictly connected with usury and were laid later, while next regulations on speculation and usury were being considered in the Sejm. What is more, from the very beginning of the legislative works on regulations against speculation and usury, speculation was not separated from usury. During the parliamentary debate on the Bill of 2 July 1920 on combating war usury it was a common view, supported for example by Władysław Leon Grzędzielski, a deputy-reporter of the draft of the proposed bill on combating war usury, that speculation was one of the greatest threats for economy, which could render impossible unification of the reborn Republic ${ }^{15}$.

To compare speculation with the other component of war usury - usury - it was rather easy to indicate the meaning of the term of speculation. However, the definition of usury is much more sophisticated since this term had a large variety of meanings throughout the history. One of the most prominent Polish legal scholars who devoted his studies to usury, Daniel Fajgenberg, Ph.D. and attorney at law at the interwar Warsaw Bar, defined usury in the legal meaning as: "any kinds of illicit gain of material profit under the cover of mutual private law contracts"16. Thus, it can be stated that in 1918 usury was not restricted only to interest and loans, but this phenomenon could occur in any transaction.

As it was mentioned before, the end of World War I and the revival of the Polish statehood were accompanied by a deep economic crisis. This assumption is of particular significance since the phenomena of usury and speculation were closely related to the contemporary economic situation - usury and speculation are the results of pathological economic situations ${ }^{17}$. Another matter of particular importance as regards war usury was the political system. It could either foster or oppose usury and speculation because legal frames of certain states can be either susceptible to usury and speculation or prone to these phenomena ${ }^{18}$. However, the role of the political system was restricted because the Republic of Poland was in the term of shaping after its revival after 123 years of the Partitions period. Another presumption which needs to be stated is that during the World War I and after it usury was predominantly regulated by penal rules, rather than by civil or administrative regulation ${ }^{19}$.

\footnotetext{
${ }^{15}$ Stenographer's report from the $158^{\text {th }}$ session of the Legislative Sejm, Biblioteka Sejmowa, https://bs.sejm.gov.pl/F? func=file\&file_name $=$ find-nowe-2rp-sejm\&local_base $=$ ars $01 \quad$ (visited October 15, 2018).

${ }^{16}$ D. Fajgenberg, Lichwa ..., p. 7.

${ }^{17} \mathrm{~J}$. Pokoj, Przeciwdziałanie lichwie wojennej w pierwszych latach II Rzeczypospolitej, „Krakowskie Studia z Historii Państwa i Prawa” 2014, Vol. 7, issue 4, pp. 630-631.

${ }^{18}$ J. Reinhold, Ustawa..., p. 8.

${ }^{19}$ Sz. Gelernter, Ustawa z dnia 2 lipca 1920 roku o zwalczaniu lichwy wojennej, Warszawa 1924, p. 3.
} 


\section{THE FIRST POLISH REGULATION IN THE FIELD OF COUNTERACTING SPECULATION AND USURY}

As it was mentioned before, the aim of this paper is to discuss the issue of regulations against speculation and usury in Poland between 1918 and 1920. At the beginning of this especially critical economic period, Polish administration and the judiciary system were forced to apply the law passed by the invader states. The particularly interesting issue is the relation between the law in force, which was actually inherited from the occupational powers (Austria, Germany and Russia), and the new regulations which were created in Poland from the very beginning of its independence.

As soon as 5 December 1918 the Decree on war usury was issued ${ }^{20}$. The fact that this regulation was adopted only just less than one month after Poland had regained its independence ${ }^{21}$, clearly shows that counteracting speculation and usury was among the most significant problems the new government was facing. This was the first Polish legislation in the field of speculation and usury. From that moment on, a few more decrees and bills in the field of speculation and usury were issued. Apart from the Decree of 5 December 1918, the most significant Polish interwar acts regarding this matter were: 1) Decree of 11 January 1919 on the creation of Authority for combating usury and speculation ${ }^{22}$, 2) Decree of 23 April 1920 on the scope of action of the Authority for combating usury and speculation $^{23}$, 3) Bill of 2 July 1920 on combating war usury, 4) Decree of the President of the Republic of Poland of 29 June 1924 on financial usury ${ }^{24}$, 5) Bill of 5 August 1938 on providing the necessities of life ${ }^{25}$.

As regards the Decree of 5 December 1918, it shall be noted that none of its provisions expressis verbis did repeal the previous regulations. What is more, the preamble of this Decree stated that it was issued in order to strengthen and expand the counteraction against speculation and usury. Thus, since 5 December 1918 there the were anti-usury and anti-speculation regulations of different origins: those inherited from the occupational powers, especially in these parts of Poland

\footnotetext{
${ }^{20}$ Journal of Laws 1918, issue 19, position 50.

${ }^{21}$ The commonly accepted date of regaining independence by Poland is 11 November 1918. On that day Józef Piłusdski took command of the Polish armed forces. Since the Bill of 23 April, 1937, the date of 11 November is officially celebrated as the anniversary of regaining independence by Poland in 1918 (except for the communist period when celebrating the Independence Day was strictly prohibited) - Article 1 of the Bill of 23 April, 1937 on the Independence Day, Journal of Laws 1937, issue 33, position 255.

${ }^{22}$ Journal of Laws 1919, issue 7, position 109.

${ }^{23}$ Journal of Laws 1920, issue 43, position 260.

${ }^{24}$ Journal of Laws 1924, issue 56, position 574.

${ }^{25}$ Journal of Laws 1938, issue 60, position 462.
} 
which had previously belonged to Austria and Germany, and those adopted on the 5 December 1918. According to Article 12, the Decree was supposed to come into force as of the day it was published; since it was published on 5 December 1918 as well, the Decree came into force on the same day when it was issued. The Decree was repealed by the aforementioned bill on combating war usury of 2 July 1920 .

Despite the fact that the Decree of 5 December 1918 was considered rather provisional, and thus as an underdeveloped regulation ${ }^{26}$, it provided a general regulation in the field of counteraction against speculation and usury. In Article 1 paragraph 1 it provided a definition of the necessities of life and depicted the offence of war usury which was subject to 2 years of imprisonment and (in conjunction) a fine up to 100,000 Polish markas or up to 150.000 of Austro-Hungarian krones. In further paragraphs the lawmaker introduced even harsher measures in order to get rid of speculation, including a seizure of life necessities. In the next articles the state reaction against speculation and usury was specified. For example, a specific offence of housing usury was described. Another interesting concept was the responsibility of chief executive officers and all members of the management. All of them were responsible for their subordinates and if any of workers committed a speculative or usurious crime, the superior was supposed to be automatically convicted, whether he was subjectively guilty or not.

All of these regulations, as the legal scholars had said, were supposed to improve the state's counteraction against the deficiencies of the contemporary economy ${ }^{27}$, struggling with shortages caused by the World War I and the border conflicts which the reborn Polish state was facing in nearly all directions ${ }^{28}$. Despite the fact that the Decree was based predominantly on the German bill of 8 May 1918 but also on the Austrian Decree of 24 March 1917, the Polish legislator did not manage to adopt a comprehensive and elaborate regulation ${ }^{29}$. However, the reaction of the state was designed to be efficient, in order to provide the population with the necessities of life as fast as possible. However, the question is whether it was possible at all to enact regulations of such features when the prior regulations were still binding and the judiciary system was not ready to apply new rules.

\footnotetext{
${ }^{26}$ D. Fajgenberg, Lichwa..., p. 116.

${ }^{27}$ Cf. J. Reinhold, Ustawa..., p. 4-5.

${ }^{28}$ W. Roszkowski, Historia Polski 1914-2004, Warszawa 2004, pp. 21-24.

${ }^{29}$ D. Fajgenberg, Lichwa..., p. 116.
} 


\section{LAW ON THE BOOKS VS. LAW IN ACTION: COMPETITIVE REGULATIONS}

Because of the fact that the regulations inherited from the occupational powers were not abrogated, the regulations provided by the Decree of 5 December 1918 were binding alongside with the prior bills. This led to a complex situation when there were competitive rules in the same fields. For example, Article 1 of the Decree of 5 December 1918 regulated the same matters as paragraph 23 of the Austrian imperial Decree from 24 March 1917. Deeper research and comparison of particular provisions clearly indicate irremovable discrepancies between the prior acts and the new one. Furthermore, the difference in interpretation could not be removed simply by using the rule lex posterior derogat legi priori, since the Decree of 5 December 1918 explicitly sustained the prior regulations in power. On the one hand, the legislator determined that the occupational regulations had become - and remained - part of the Polish legal order, while on the other hand, there was no single directive determinintg how to interpret the regulations being in force in order to avoid the collision of norms.

Therefore the question that should be asked is: how was it possible for a state to tolerate parallel regulations in the same field? This is not a rhetorical question since in the Polish legal history, especially in the $20^{\text {th }}$ century, it is raised quite often. To answer the aforementioned question it is necessary to focus on the problem of competitiveness between various regulations in the field of speculation and usury. Except for the Decree of 5 December 1918 there were, as it was mentioned before, other binding anti-speculation and anti-usury regulations. As the Decree did not abrogate the prior regulations, these were still in force and remained somehow competitive to the new rules provided by the Decree of 5 December 1918. The fact of the duality of the law on the books and law in action was even deepened by the legal scholars. In fact, not many of them cared about the phenomena of speculation and usury, since in the beginning of the Second Polish Republic there were numerous fields of legal interest for legal scholars, especially as regards constitutional law.

However, those who did, did not rise to the challenge. The main actor on the scene, Daniel Fajgenberg, usually restricted his considerations to purely academic issues, leaving the legal practice apart. Another one, Józef Reinhold, despite the fact that he was a defence lawyer and later on a barrister at the Krakow's Bar Association $^{30}$, and therefore had practice in legal aspects of speculation and usury,

${ }^{30}$ A. Dziadzio, Józef Reinhold (1884-1928) - ,zapomniany” profesor prawa karnego Uniwersytetu Jagiellońskiego, „Krakowskie Studia z Historii Państwa i Prawa” 2014, Vol.7, issue 2, p. 271. 
did not reveal his practical knowledge in his publications. The main difference among those who showed any interest in speculation and usury was whether the Decree on war usury from 5 December 1918 was the first "major regulation in the field of substantive penal law" 31 after the rebirth of Poland, or whether this honour should be assigned to the bill of 2 July 1920 on combating war usury ${ }^{32}$. The first viewpoint was represented by Daniel Fajgenberg from the University of Warsaw, while the other one by Professor Józef Reinhold from the Jagiellonian University in Kraków. However, neither of them bothered to think whether the coexistence of different regulations in the same fields of interest was a normal situation in a sovereign state.

\section{CONCLUSION}

As it was already said, speculation is especially dangerous in case of young economies, which are deprived of a solid foundation and are prone to pathological economic phenomena. If the disadvantageous economic condition is caused by war and lasts for a certain period of time, speculation might be accompanied by usury, and result in a perilous situation of war usury. This kind of socio-economic situation occurred in Poland after the end of the World War I and the revival of the Polish statehood. During the parliamentary debate on the Bill of 2 July 1920 on combating war usury ${ }^{33}$ it was commonly held view that speculation had been up to then one of the greatest threats for economy, which could render impossible unification of the reborn Republic's economy. Thus, in the legislative motives to the aforementioned bill it was clearly stated that high prices are "mainly or even always caused by anticompetitive speculation" 34 . However, high prices were not the only result of speculation and usury, and not even the most severe one. In a particularly difficult economic situation, e.g. during and after the war or during an economic crisis, this phenomenon could cause shortages of the necessities of life. Consequently, the economic situation could simply lead to a major political turmoil or even a revolution.

Both usury and speculation seem to be related phenomena which the Polish state had to face just after it was reborn after 123 years of political subordination. The reaction against usurious and speculative crimes was immediate: in less than a month after the formal date of regaining independence, the Polish lawmaker

\footnotetext{
${ }^{31}$ D. Fajgenberg, Lichwa..., p. 116.

${ }^{32}$ J. Reinhold, Ustawa ..., p. 8.

${ }_{33}$ Journal of Laws 1920, issue 67, position 449.

${ }^{34}$ J. Reinhold, Ustawa ..., p. 4.
} 
issued a Decree against speculation and usury. However, the text was not brilliant. As it allowed the usage of the prior regulations, it led to an even greater disorder than it was before. There can be no justification for such a discrepancy between law on the books and law in action as it was depicted before. The natural and unstoppable will to replace the prior regulations with new Polish ones resulted in a detrimental state of uncertainty which was not fixed until the Bill of 2 July1920 on combating war usury.

\section{BIBLIOGRAPHY}

Bardach J., Leśnodorski B., Pietrzak M., Historia ustroju i prawa polskiego, Warszawa 2005

Brzoza Cz., Sowa A.L., Historia Polski 1918-1945, Kraków 2006

Davies N., God's Playground, Vol. 2, 1795 to the present, Oxford 2005

Dziadzio A., Józef Reinhold (1884-1928) - ,zapomniany” profesor prawa karnego Uniwersytetu Jagiellońskiego, „Krakowskie Studia z Historii Państwa i Prawa” 2014, Vol. 7, issue 2

Fajgenberg D., Lichwa. Rozprawa doktorska przyjęta przez Radę Wydziatu Prawa Uniwersytetu Warszawskiego, Warszawa 1932

Gelernter Sz., Ustawa z dnia 2 lipca 1920 roku o zwalczaniu lichwy wojennej, Warszawa 1924

Grodziski S., Komisja Kodyfikacyjna Rzeczypospolitej Polskiej, “Czasopismo Prawno-Historyczne" 1981, Vol. 33, issue 1

Jastrzębski R., Opinia w sprawie możliwości dochodzenia przez Polskę od Niemiec odszkodowania za szkody spowodowane przez druga wojnę światowa w związu z umowami międzynarodowymi, „Przegląd Sejmowy” 2017, Vol. 143, issue 6

Journal of Laws 1918, issue 19, position 50

Journal of Laws 1919, issue 7, position 109

Journal of Laws 1919, issue 44, position 315

Journal of Laws 1920, issue 43, position 260

Journal of Laws 1920, issue 67, position 449

Journal of Laws 1924, issue 56, position 574

Journal of Laws 1937, issue 33, position 255

Journal of Laws 1938, issue 60, position 462

Landau Z., Tomaszewski J., Gospodarka Drugiej Rzeczypospolitej, „Dzieje Narodu i Państwa Polskiego" Vol. 63, Warszawa 1991

Płaza S., Historia prawa w Polsce na tle porównawczym, Vol. 3, Okres międzywojenny, Kraków 2001

Pobóg-Malinowski W., Najnowsza historia polityczna Polski, Vol. 2, 1919-1939, London 1956

Pokoj J., Przeciwdziatanie lichwie wojennej w pierwszych latach II Rzeczypospolitej, „Krakowskie Studia z Historii Państwa i Prawa” 2014, Vol. 7, issue 4

Reichsgesetzblatt 1918, No. 395 
Reichs-Gesetz-Blatt für das Kaiserthum Österreich 1917, No. 131

Reinhold J., Bill on combating war usury with relevant decrees of Minister of Supply, Warszawa, Kraków 1921

Roszkowski W., Historia Polski 1914-2004, Warszawa 2004

Stachura P.D., Poland in the Twentieth Century, London 1999

Stachura P.D., Poland 1918-1945, London, New York 2004

Stenographer's report from the $158^{\text {th }}$ session of the Legislative Sejm, Biblioteka Sejmowa, https://bs.sejm.gov.pl/F?func=file\&file_name=find-nowe-2rp-sejm\&local_base$=\operatorname{ars} 01$ (visited October 15, 2018)

The History of Poland since 1863, R.F. Leslie (ed.), Cambridge 1980

\section{Summary}

The aim of this paper is to analyse the issue of regulations against speculation and usury in the first years of the Second Polish Republic (1918-1920). The long period of World War I resulted in a major economic shock and long-lasting condition of shortages of commodities, including the necessities of life. This situation had a terrific impact on politics and forced the Polish legislator to react. As soon as 5 December 1918 a Decree on war usury was issued. The regulation in the field of war usury identified several types of illicit acts and contained basic rules of a particular procedure which was supplementary to the common penal procedures. Due to a low level of legislation, the regulation was defective and incoherent with the system of the law. Since the previous regulation was still in force, a dissonance between law on the books and law in action occurred. Furthermore, due to provisions contained in the Decree it was not possible to eliminate the discrepancy thanks to common rules of interpretation of legal texts such as lex posterior derogat legi priori.

\section{KEYWORDS}

speculation, usury, war usury, Poland, war, necessities of life

\section{SŁOWA KLUCZOWE}

spekulacja, lichwa, lichwa w czasie wojny, Polska, wojna, podstawowe potrzeby życiowe 